\title{
Assessment of application of selected waste for production of biogas
}

\author{
Monika Pawlita-Posmyk ${ }^{1}$, and Matgorzata Wzorek $^{1, *}$ \\ ${ }^{1}$ Department of Process Engineering, Faculty of Mechanical Engineering, Opole University of Technology, Opole, Poland
}

\begin{abstract}
Recently, the idea of biogas production has become a popular topic in Poland. Biogas is a valuable source of renewable energy with a potential application in electricity and heat production. Numerous types of technological solutions of biogas production are closely linked to the availability of substrates in the area, as well as their quantity and their properties. The paper presents the assessment of application in biogas production selected wastes such as communal and household sewage sludge and waste from a paper production in Opole region (Poland). The annual productions of methane, biogas and electricity were estimated. Chosen physico-chemical properties important in fermentation process were taken into consideration in the assessment. The highest value of potential energy was obtained using waste from the paper industry but the most appropriate parameters for this process has sewage sludge from the municipal sewage treatment plant. The use of sewage sludge from domestic and municipal sewage and waste from the paper industry creates the opportunity to reduce the amount of waste materials.
\end{abstract}

\section{Introduction}

In Poland, the production of biogas derived from waste materials gains in popularity and the number of biogas plants is rising [1-3]. In 2016, in Poland, the register of the President of the Agricultural Market Agency (ARR) included 94 agricultural biogas installations on the list of biogas manufacturers. Their total installed electrical capacity was equal to $101.234 \mathrm{MW}$ (this means a $21 \%$ increase in relation to 2015) [4].

The methane fermentation in a biogas plant involves biogas production through a process involving four phases (hydrolysis, acidogenesis, acetogenesis and methanogenesis) [5] on the basis of resources with various volume ratios of hydrocarbons, lipids and proteins [6-7]. The composition of such biogas is different depending on the applied substrates, however, typically it consists mostly of $\mathrm{CH}_{4}(40-70 \%)$ and $\mathrm{CO}_{2}$ (15-60\%) as well as other compounds in small amounts: $\mathrm{H}_{2} \mathrm{O}(2-7 \%), \mathrm{N}_{2}(2-5 \%), \mathrm{O}_{2}(0-2 \%)<1 \% \mathrm{H}_{2}, \mathrm{NH}_{3}(0-1 \%)$ and $\mathrm{H}_{2} \mathrm{~S}(0.005-2 \%)$ [5, 8-11]). The principal sources of biomass include: agricultural waste, communal solid waste, sewage sludge, forestry waste as well as industrial and animal remains, etc. [12]. According to [13] another interesting solution suitable for biogas production from waste is digestion of poultry manure or litter.

Agriculture forms the principal source of biodegradable waste. On the basis of data as of 2016, the ratios of the resources applied in the production of agricultural biogas are as follows [4]:

- slurry $24.04 \%$,

- fruit and vegetable remains $20.64 \%$,
- distillery stillage $14.81 \%$,

- maize silage $13.62 \%$,

- beet pulp $6.89 \%$,

- sludge from food and agricultural industry $3.88 \%$,

- sludge obtained from dairy production $2.76 \%$,

- sewage $2.67 \%$,

- green forage $1.76 \%$,

- other $8.93 \%$.

These resources were applied in the production of 250 million $\mathrm{m}^{3}$ of biogas in 2016 (i.e. an increase of $21 \%$ in relation to 2015). In total, the production of electricity derived from agricultural biogas was equal to 524.6 GWh [4]. Nevertheless, the production of biogas in an anaerobic digestion is small in relation to the available technical potential [14].

The production of biogas is an important option in managing the existing wastes, as this process applies organic matter, which is difficult in application by other methods. In addition, biogas plants can aid in the utilization of waste produced in a given area, as the waste can be used locally.

Sludge from communal wastewater treatment plants and domestic treatment plants form one group of waste whose application can be potentially problematic. Although communal sludge obtained in wastewater treatment plants has been considered to be an adequate substrate for the production of biogas in large wastewater treatment plants for a long time, some areas, such as Opole province face a problem associated with its utilization.

Communal sewage sludge forms a considerable hazard to the environment due to its large volume and the

* Corresponding author: m.wzorek@po.opole.pl 
chemical composition.

In the last years, the dynamic development of domestic sewage treatment plants has led to a considerable increase in the volume of waste being produced in such facilities. On the basis of data obtained from the Central Statistical Office $[15,16]$, the number of domestic sewage treatment plants increased from 181,000 in 2014 to around 203,000 in 2015.

The majorities, i.e. almost $85 \%$ of wastewater treatment facilities applied in individual households are located in rural areas (around $84 \%$ of underground containers without drainage systems and $92 \%$ of domestic sewage treatment plants). The variability of the physicochemical properties of waste from domestic sewage treatment plants leads to the refusal to accept this type of waste by the communal wastewater plants due to the potential destabilizing effect of this waste in the normal treatment process. Hence, other measures are sought to further process this type of waste.

Waste obtained from the paper industry forms another group of waste posing a problem with its utilization. A large volume of waste in the form biomass originates from the processes in the cellulose and paper industry and its storage poses a hazard to the environment. The problems are associated with the high moisture content in this type waste, which is coupled with the large volume and variability in its composition. The methods applied to process this waste are often too expensive and in some cases their impact on the environment can be problematic. In 2011, the overall production of this waste was equal to 932,900 tons, and in 2013 , the production and processing of cellulose mass, paper and cardboard produced 1,085,000 tons of waste [19].

The objective of this paper is to assess the potential for the use of substrates formed by waste derived from communal and household sewage treatment plant and waste from a paper production plant applied in the production of biogas. The use of these substrates in the methane fermentation process could lead to the solution of a problem associated with the utilization of waste in the area of the Opole province (Poland).

\section{Materials and methods}

\subsection{Substrates}

The assessment of the properties that are important in the context of the application in biogas production involved a study involving four types of waste derived from facilities located in the Opole province.

The sludge that was identified for the study came from two domestic sewage treatment plants (DSS I, DSS II), sewage sludge from a communal wastewater treatment plant (SS) and post-processing waste from paper production $(\mathrm{PW})$.

The assessment of the properties of sludge obtained from domestic wastewater treatment applied from two facilities. The first of them is a domestic sewage treatment plant comprising a dual biological zone with a fluidized bed. This facility consists of an initial settling tank and two independent zones applied for an aerobic conditioning and a secondary tank. This plant is installed as an onsite facility for a single-family house occupied by a family of four and has been constantly applied for a period of 4 years. The other sewage treatment plant applied in the research comprises a two-chamber tank coupled with a drainage system. A single family of three uses this facility. It has been in use for 5 years.

Another type of the waste used in this study was formed by communal sewage sludge originating from a mechanical-biological wastewater treatment plant capable of increased treatment of biogens (WWTP). This plant was designed for a load of 225,000 population equivalent (PE) of waste, i.e. $45000 \mathrm{~m}^{3}$ per day.

The annual volume of waste conditioned by the plant is equal to around $96,966,000 \mathrm{~m}^{3}$ per year (including $12 \%$ of wastewater from industry) [18]. The sewage sludge samples were extracted from waste mixing chamber (i.e. sludge was obtained from the compactors that were dehydrated in the compactor and the initial settling tank). The post-processing waste from the paper industry made up the third type of the waste. The waste samples were extracted following the dehydration process (i.e. the composition of the waste was $40 \%$ dry mass) from the prisms where it is stored prior to its treatment or disposal.

\subsection{Analysis methods}

The sewage sludge and the waste from the paper industry were extracted and analyzed in accordance with the standards in force. The analysis involved the list of the following indicators:

- water content in accordance with PN-EN 12880:2004,

- $\mathrm{pH}$ in accordance with PN-EN 12176:2004,

- dry mass in accordance with PN-EN 12879:2004,

- total phosphorus in accordance with PN-EN 13346:2002, PN-EN ISO 11885:2009,

- total Kjeldahl nitrogen in accordance with PN-EN 13342:2002,

- ammoniacal nitrogen, in accordance with PN-75/C04576/15,

- heavy metal concentration: $\mathrm{Cd}, \mathrm{Cr}, \mathrm{Cu}, \mathrm{Ni}, \mathrm{Pb}, \mathrm{Zn}$, in accordance with PN-EN 13346:2002, PN-EN ISO 11885:2009 and $\mathrm{Hg}$ in accordance with PN-EN 13346:2002, PN-EN 1483:2007,

- magnesium in accordance with PN-EN 13346:2002, PN-EN ISO 11885: 2009,

- total organic carbon (TOC) in accordance with PB/FCH/17/ B:10.04. 2013.

\section{Results and discussion}

The analysis was initiated by assessing the total volume of the production of the waste in the area of the Opole province as well as in Poland with the purpose of determining the potential for biogas production from the waste.

The rough calculations were performed on the basis of the following relations:

- methane production (MP) [19] 


$$
\mathrm{MP}=\mathrm{AW} \times \mathrm{DM} \times \mathrm{OM} \times \mathrm{PCH}_{4}
$$

- biogas production (BP) [19]

$$
\mathrm{BP}=\mathrm{MP} \times \% \mathrm{CH}_{4}
$$

- electricity production (EP) [20]:

$$
\mathrm{EP}=\mathrm{MP} \times \mathrm{GCV}_{\mathrm{CH} 4} \times \eta_{E L}
$$

where: AW - amount of waste production per year, DM - dry mass content, $\mathrm{OM}$ - organic matter content in the waste, $\mathrm{PCH}_{4}$ - potential for methane production (on the basis of an assumption that 1 ton of waste gives $100 \mathrm{~m}^{3}$ of biogas), $\% \mathrm{CH}_{4}$ methane content in the biogas (on the basis of an assumption it is $60 \%), \mathrm{GCV}_{\mathrm{CH} 4}-$ calorific value of methane $\left(9.17 \mathrm{kWh} / \mathrm{m}^{3}\right)$ $\eta_{\mathrm{EL}}-$ efficiency of electricity production (35\% [20]).

Table 1 contains a summary of the input data taken for calculations and the estimated production of biogas and electricity. the course of the methane fermentation, and in particular on the stability of the process is associated with the maintenance of waste is $\mathrm{pH}$. The optimum value of $\mathrm{pH}$ should be in the range from $6.5-8.0$, which guarantees the beneficial environment for the growth of anaerobic bacteria [26]. An increase of $\mathrm{pH}$ above 8.5 makes the environment toxic for them [27-28]. The examined waste had a $\mathrm{pH}$ values that were slightly acid, (DSS I, DSS II, $\mathrm{SS}$ ), and even neutral one (PW).

All waste materials taken for comparison purposes demonstrated a high water content (i.e. from $66.5 \%$ to $98.5 \%$ with a note that the greatest value was recorded for household sewage treatment plant DSS II). The high water content is important in the aspect of the digestion process conducted by bacteria, as well as for their longevity and for obtaining gas that is rich in $\mathrm{CH}_{4}$.

Matheri et al. [28] recommend that the moisture content in the process of methane fermentation should be equal to $90 \%$.

One of the key parameters in terms of the efficiency of

\begin{tabular}{|c|c|c|c|c|c|c|c|}
\hline & Unit & $\mathrm{DSS}^{1}$ & $\mathrm{DSS}^{2}$ & $\mathrm{SS}^{1}$ & $\mathrm{SS}^{2}$ & $\mathrm{PW}^{1}$ & $\mathrm{PW}^{2}$ \\
\hline Dry mass (DM) & $\%$ d.m. & \multicolumn{2}{|c|}{2.65} & \multicolumn{2}{|c|}{4.00} & \multicolumn{2}{|c|}{33.5} \\
\hline $\begin{array}{c}\text { Organic matter } \\
(\mathrm{OM})\end{array}$ & $\%$ d.m. & \multicolumn{2}{|c|}{83.4} & \multicolumn{2}{|c|}{75.4} & \multicolumn{2}{|c|}{31.3} \\
\hline $\begin{array}{c}\text { Amount of waste } \\
\text { (AW) }\end{array}$ & $\mathrm{t} /$ year & $467,712^{3}$ & $11,520^{3}$ & $\begin{array}{l}555,982 \\
\text { (d.m.) }\end{array}$ & $\begin{array}{l}16,487 \\
\text { (d.m.) }\end{array}$ & $1,085,500$ & 47,207 \\
\hline $\begin{array}{c}\text { Biogas production } \\
\text { (BP) }\end{array}$ & $\mathrm{m}^{3} /$ year & $1,722,817.15$ & $42,433.92$ & $2,794,736.2$ & $82,874.65$ & $18,970,017.08$ & $824,981.65$ \\
\hline \multirow{2}{*}{$\begin{array}{l}\text { Methane production } \\
\text { (MP) }\end{array}$} & $\mathrm{m}^{3} /$ year & $1,033,690.29$ & $25,460.35$ & $1,676,841.7$ & $49,724.79$ & $11,382,010.25$ & $494,988.99$ \\
\hline & $\mathrm{m}^{3} / \mathrm{h}$ & 118.00 & 2.91 & 191.42 & 5.68 & $1,299.32$ & 56.51 \\
\hline $\begin{array}{c}\text { Electricity } \\
\text { production (EP) }\end{array}$ & $\begin{array}{l}\mathrm{MWh} / \\
\text { year }\end{array}$ & $3,317.63$ & $8,171.45$ & $5,381.82$ & $15,959.30$ & $36,530.56$ & $1,588.67$ \\
\hline
\end{tabular}
biogas production is associated with the high content of

Table 1. Production of waste, methane, biogas and electricity from selected waste substrates.

${ }^{1}$ - on the national scale, ${ }^{2}$ - on the scale of the Opole province, ${ }^{3}$ - calculations under the assumption that there are 203,000 domestic sewage treatment plants in Poland [15]; 5,000 - number of domestic sewage treatment plants in the Opole province; of which sewage sludge forms about $1-2 \%$ by volume; $2.4 \mathrm{~m}^{3} /$ person $\cdot$ month- standardized water use per inhabitant in a household [21]; households comprising a domestic sewage treatment plant consists of 4 people.

The waste from the paper industry (PW) has the greatest potential for biogas production. This is due to the amount of the waste generated both locally and on the national scale. The potential for biogas production of the waste originating from the communal wastewater treatment plant and domestic sewage plants can give the production of $8,699.45 \mathrm{MWh} /$ year of electricity on the national scale and $24,130 \mathrm{MWh} /$ year on the scale of the Opole province. If we were to use all available waste for biogas production, we can reduce its amount by $2,109,194$ tons per year on the national scale and by 75,214 tons per year on the scale of the Opole province. The applied waste can yield $23,487,570.42 \mathrm{~m}^{3}$ of biogas per year on the national scale and $950,290.22 \mathrm{~m}^{3}$ per year on the scale of the Opole province.

We need to note that the waste applied in the methane fermentation must be characterized by adequate properties. The results of the analysis involving physicochemical properties of the waste are presented in Table 2 and the data is compared with the results with regard to the most common substrates used in biogas production. One of the parameters having a considerable impact on the organic matter in the waste. It determines the course of the fermentation process and the volume of the biogas. During the course of the microbiological processes, the amount of organic matter in the waste decreases in time and, as a consequence, a decrease of the amount of methane production occurs, and the profitability of the process drops with the smaller potential for application for energy production. Various substances undergo disintegration at a different pace.

Among the analyzed materials, the waste from the paper industry demonstrates the lowest content of organic substances $(31.3 \%$ d.m. $)$. This value is also two times lower from the water content in both the domestic sewage plant and communal wastewater treatment plants. The study did not also establish considerable differences between the properties of the sludge from various domestic sewage treatment plants. The total phosphorus concentration is marginally present in the analyzed waste. In the sludge from WWTP the concentration of phosphorus is at a level of $1.81 \%$ d.m., whereas for DSS I and DSS II the values are equal to $0.586 \%$ d.m. and $0.504 \%$ d.m., respectively (i.e. a 
Table 2. Physico-chemical properties of waste and other substrate tested by the authors.

\begin{tabular}{|c|c|c|c|c|c|c|c|c|c|}
\hline \multirow{2}{*}{\multicolumn{2}{|c|}{ Parameter }} & \multirow[t]{2}{*}{ Unit } & \multicolumn{4}{|c|}{ Waste } & \multirow{2}{*}{$\begin{array}{c}\text { Cattle } \\
\text { slurry } \\
{[25,26]}\end{array}$} & \multirow{2}{*}{$\begin{array}{l}\text { Cattle } \\
\text { manure } \\
{[25-27]}\end{array}$} & \multirow{2}{*}{$\begin{array}{c}\text { Maize } \\
\text { silage } \\
{[26,28]}\end{array}$} \\
\hline & & & DSS I & DSS II & SS & $\mathrm{PW}$ & & & \\
\hline \multicolumn{2}{|c|}{ Water content } & $\%$ & 96.2 & 98.5 & 96.0 & 66.5 & $88.0-95.0$ & $67.0-87.0$ & - \\
\hline \multicolumn{2}{|c|}{$\mathrm{pH}$} & - & 6.8 & 6.2 & 6.3 & 7.0 & - & 7.7 & - \\
\hline \multicolumn{2}{|c|}{$\begin{array}{c}\text { Content of } \\
\text { organic } \\
\text { substances }\end{array}$} & $\%$ d.m. & 84.4 & 82.4 & 75.4 & 31.3 & $75.0-85.0$ & $68.0-76.0$ & 95.6 \\
\hline \multicolumn{2}{|c|}{$\begin{array}{c}\text { Total } \\
\text { phosphorus }\end{array}$} & $\%$ d.m. & 0.586 & 0.504 & 1.81 & 0.058 & - & - & 0.24 \\
\hline \multicolumn{2}{|c|}{ Total nitrogen } & $\%$ d.m. & 4.47 & 3.44 & 5.70 & 0.47 & $2.6-6.7$ & $1.1-3.4$ & 1.76 \\
\hline \multicolumn{2}{|c|}{$\begin{array}{c}\text { Ammoniacal } \\
\text { nitrogen }\end{array}$} & $\%$ d.m. & 0.35 & $<0.01$ & 0.36 & 0.06 & - & - & 0.16 \\
\hline \multicolumn{2}{|c|}{ Magnesium } & $\%$ d.m. & 0.18 & 0.27 & 0.33 & 0.35 & $0.3-0.7$ & 1.3 & 0.12 \\
\hline \multicolumn{2}{|c|}{ TOC } & $\%$ d.m. & 55.0 & 50.1 & 44.9 & 10.0 & - & - & - \\
\hline \multicolumn{2}{|c|}{$\mathrm{C}: \mathrm{N}$} & - & $12.3: 1$ & $14.6: 1$ & $7.9: 1$ & $21.3: 1$ & $6-20: 1$ & $11-30: 1$ & $32.7: 1$ \\
\hline \multirow{7}{*}{ 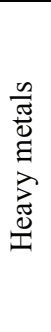 } & $\mathrm{Cd}$ & $\mathrm{mg} / \mathrm{kg}$ d.m. & 0.759 & 0.910 & 0.827 & 0.186 & 0.30 & 0.29 & $0.07-0.20$ \\
\hline & $\mathrm{Cr}$ & $\mathrm{mg} / \mathrm{kg}$ d.m. & 8.83 & 21.10 & 48.20 & 12.30 & 7.30 & 12.90 & $0.50-0.78$ \\
\hline & $\mathrm{Cu}$ & $\mathrm{mg} / \mathrm{kg}$ d.m. & 360.0 & 136.0 & 107.0 & 76.4 & 44.5 & 39.0 & $2.59-5.0$ \\
\hline & $\mathrm{Ni}$ & $\mathrm{mg} / \mathrm{kg}$ d.m. & 9.13 & 9.13 & 18.90 & 4.30 & 5.90 & 5.20 & $0.30-5.00$ \\
\hline & $\mathrm{Pb}$ & $\mathrm{mg} / \mathrm{kg}$ d.m. & 18.9 & 20.8 & 20.0 & 21.5 & 7.7 & 30.0 & $0,7-2.0$ \\
\hline & $\mathrm{Zn}$ & $\mathrm{mg} / \mathrm{kg}$ d.m. & 1161 & 614 & 1078 & 98.7 & 270 & 190 & $15.1-56$ \\
\hline & $\mathrm{Hg}$ & $\mathrm{mg} / \mathrm{kg}$ d.m. & $<0.05$ & 0.07 & 0.42 & $<0.05$ & 0.06 & 0.03 & 0.01 \\
\hline
\end{tabular}

d.m. - dry mass

difference of $0.082 \%$ d.m.).

The content of the total phosphorus in the waste from the paper industry is lower in comparison to the remaining results (i.e. over 10 times lower in relation to the sludge from the domestic sewage treatment plants (DSS I and II), and 31 times lower in comparison to the sludge from the communal wastewater treatment plant (in comparison to the result recorded for maize silage).

The total content of the organic carbon forms an important consideration, as its content in the substrate affects the activity of the bacteria.

The sludge from the domestic sewage treatment plant DSS I had 5 times greater content of the organic carbon from the waste from the paper industry $(10 \% \mathrm{~d} . \mathrm{m}$.) and was characterized by the smallest concentration of the total nitrogen $(0.47 \%$ d.m.) among the analyzed waste. The sludge from the communal wastewater treatment plant also demonstrated over 4 times greater TOC content in comparison to the waste from the paper industry. The sludge from both domestic sewage treatment plants had a similar content of the organic carbon (a difference of $4.9 \%$ d.m. was noted). The content of the total nitrogen in the examined waste was in the range from 0.47 to $6.70 \% \mathrm{~d}$.m. The lowest concentration of the ammoniacal nitrogen was registered in the waste from the domestic sewage treatment plant DSS II, whereas the concentration of the ammoniacal nitrogen in DSS I and SS was almost at the same level. An optimum ratio of carbon, nitrogen and phosphorus (C:N:P) of 100:3:1 is an important condition for the gaining [29-30] a high efficiency of $\mathrm{CH}_{4}$ production. In order to ensure that the anaerobic fermentation is performed in the conditions of an optimum $\mathrm{C}: \mathrm{N}$ ratio, the biodegradable material should demonstrate a high $\mathrm{C}: \mathrm{N}$ ratio [25,31]. The insights from the literature offer various ranges of the $\mathrm{C}: \mathrm{N}$ ratio to achieve the adequate course of the methane fermentation process. Abbasi et al. [32] give that this ratio should be 20-30:1, whereas the work [24,33] describes an experiment conducted in the conditions when the $\mathrm{C}: \mathrm{N}$ ratio was 15-30:1. However, these authors found that microorganisms should have a ration of $\mathrm{C}: \mathrm{N}$ 20-30:1 to ensure their optimum growth [24,31]. Another range of the $\mathrm{C}: \mathrm{N}$ that was found to be optimum for the composition of the input for biogas production is equal to $10-25: 1$. The ratio of $\mathrm{C}: \mathrm{N}$ in the waste, including DSS I, DSS II, PW, cattle slurry and cattle manure was adequate in this respect, whereas for SS it was equal to $7.9: 1$, which is far below the optimum value for the anaerobic process. For the case when the $\mathrm{C}: \mathrm{N}$ ratio is too low (i.e. $<10: 1$ ), nitrogen is released in the form of annonia, and this leads to the increase of the environment $\mathrm{pH}$ [25].

Another important condition, which affects the course of biogas production, is associated with the heavy metal content in the waste. It is necessary to reduce the amount of heavy metals in the substrates to a minimum by applying a process of selection of substrates used in the fermentation process.

However, not all metals have a negative impact on this process. The growth of microorganisms requires an adequate content of magnesium and trace elements such as copper and zinc [34].

The content of magnesium has a particular impact on the growth rate of microorganisms and this impact is similar 
to the role of basic nutrients. While the moderate concentrations stimulate the growth of the bacteria, excessive concentrations reduce this growth and even greater can play a considerably inhibitory effect on the process and even lead to toxicity [35]. The content of magnesium in the range from 1000 to $1500 \mathrm{mg} / \mathrm{l}$ can have a moderately slowing effect, whereas the range starting from $3000 \mathrm{mg} / \mathrm{l}$ can stop the growth of microorganisms altogether [36]. The content of $\mathrm{Mg}$ in the analyzed waste was only marginal, as we recorded $0.12-1.3 \mathrm{mg} / \mathrm{kg}$ d.m.

The waste applied for the testing has a various content of heavy metals. From the analysis of heavy metals, we learned that DSS I and II have a low content of heavy metals, just as for the case reported with regard to another domestic sewage treatment plant [37]. Such small volumes should not considerably affect the fermentation process. Heavy metals can occur in higher concentrations in communal waste and sludge [38, 39,40]. The diversity of the substrates, bacteria strains and environmental factors offer the explanation to the variability of the heavy metal concentrations, as well as their relative toxicity $[35,41]$. The inhibitory effect accompanied by the reduction of the production of biogas was reported for the cases when: $\mathrm{Cu}-40 \mathrm{mg} / \mathrm{l}$, Ni$10 \mathrm{mg} / 1$, Cd-70mg/1, Pb-340mg/1, Zn-400mg/1, $\mathrm{Cr}^{3+}$ $130 \mathrm{mg} / 1, \mathrm{Cr}^{6+}-110 \mathrm{mg} / 1$ [36]. The concentration of heavy metals in the waste from the paper industry is similar to the result gained for the cattle manure, yet with a note that the latter contains more $\mathrm{Cu}$. The tested waste, have a greater $\mathrm{Zn}$ concentration (614-1161 $\mathrm{mg} / \mathrm{kg}$ d.m.) compared to the cattle slurry, cattle manure and maize silage (15.1-270 mg/kg d.m.). Among all analyzed types of waste, we learned that DSS I, DSS II, SS and PW were characterized by the highest values of $\mathrm{Cu}$ concentration (76.4-360 mg/kg d.m.). The concentration of Cr in DSS II (21.10 mg/kg d.m.) and SS (48.20 mg/kg d.m.) was higher in comparison to other types of waste (0.50-12.90 $\mathrm{mg} / \mathrm{kg}$ d.m.). In addition, SS had a considerable level of $\mathrm{Ni}$ content $(18.90 \mathrm{mg} / \mathrm{kg} \mathrm{d}$.m.).

\section{Conclusions}

Poland is a country with a considerable potential for biogas production, which can be applied in the methane fermentation process, among others based on waste. This process can involve the use of a wide range of organic waste, which is considered as noxious waste in terms of its utilization potential.

The examined waste is characterized by a considerable potential for use in biogas production. In particular, it can be applied jointly in co-fermentation with other substrates. It can form a cheap and easily accessible substrate for the production of biogas in the facilities that are already in operation.

The tested sewage sludge derived from domestic sewage treatment plants and a communal wastewater treatment plant demonstrates adequate physico-chemical properties for this purpose. This in particular refers to the adequate content of organic parts, TOC and nitrogen concentration. In addition, the concentration of heavy metals was low, which suggests that the amount available in the substrate should not have a negative impact on the fermentation process.

The application of sewage sludge in the production of biogas obtained from domestic sewage treatment plants, communal wastewater treatment plants and waste from the paper industry can offer an opportunity to solve the existing problem associated with utilization of this type of waste in the Opole province. The use of biogas for energy production can have a positive effect on the overall condition of the environment as well on the energy balance on the scale of the domestic economy. A considerable advantage associated with the use of selected substrates is associated with their accessibility, low cost of acquiring it and providing a solution to its utilization.

\section{References}

1. E.S. Energimyndigheten, ES 3 (2015)

2. M. Svensson, D. Baxter. IEA Bioenergy Task 37 (2015)

3. R. Feiz, J. Ammenberg, Resour. Conserv. Recycl. 122 (2017)

4. Agricultural Market Agency, www.arr.gov.pl, (18.06.2017)

5. A. Fontana, V. Patrone, E. Puglisi, L. Morelli, D. Bassi, M. Garuti, L. Rossi, F. Cappa, Bioresour. Technol. 218 (2016)

6. I. Angelidaki, D. Karakashev, D. J. Batstone, C. M. Plugge, A. J. M. Stams, Methods in Methane Metabolism, (Part A. Academic Press, 2011)

7. J. Ammenberg, R. Feiz, Resour. Conserv. Recycl. 122 (2017)

8. M. Franco-Morgado, C. Alcántara, A. Noyola, R. Muñoz, A. González-Sánchez, Sci. Total Environ. 592 (2017)

9. A. Akbulut, Energy 44 (2012)

10. Y. Shen, J. L. Linville, M. Urgun-Demirtas, M. Mintz, S. W. Snyder, Renew. Sust. Energ. Rev. 50 346-362 (2015)

11. A.S. Mehr, M. Gandiglio, M. Mosayeb Nezhad, A. Lanzini, D.M.S. Mahmoudi, M. Yari, M. Santarelli, Appl. Energ. 191 (2017)

12. Y. Santosh, T.R. Sreekrishnan, Koli S., Rana V. Bioresource Technol. 95, 1 (2004)

13. M. Tańczuk, R. Junga, S. Werle, M. Chabiński, Ł. Ziółkowski, Renewable Energy (2017) http://dx.doi.org/10.1016/j.renene.2017.05.074

14. M. Börjesson, E. Ahlgren, Energy 48 (2012)

15. Central Statistical Office, Warsaw 2016 www.stat.gov.pl (18.06.2017)

16. Central Statistical Office, Warsaw 2015 www.stat.gov.pl (18.06.2017)

17. National Waste Management Plan - update 2014, Warsaw (2015) [in Polish] 
18. Statement of WIOŚ Opole nb. 1/W/2016, Opole 2016 [in Polish]

19. J. J. Chávez-Fuentes, A. Capobianco, J. Barbušová, M. Hutňan, Waste Biomass Valorization, 8,5 (2017)

20. M. Tańczuk, W. Kostowski, M. Karaś, Energy Convers. Manage. 125 (2016)

21. Ordinance of the Minister of Infrastructure of January 14, 2002 on the definition of average standards of water consumption, (J. Act No 8, item 70)

22. S.O. Dahunsi, S. Oranusi, V.E. Efeovbokhan, J. Cleaner Prod. 156 (2017)

23. R. Kigozi, AO Aboyade, E. Muzenda, Proceedings of the World Congress on Engineering and Computer Science (2014)

24. A.N. Matheri, S.N. Ndiweni, M. Belaid, E. Muzenda, R. Hubert, Renewable Sustainable Energy Rev. 80 (2017)

25. A. Jędrczak, Biological waste processing (PWN, Warsaw, 2008) [in Polish]

26. www.agengpol.pl (25.07.2017)

27. L. Zhu, Ch. Yan, Z. Li, Bioresour. Technol. 220 (2016)

28. M. Fugol, H. Prask, Inż. Rolnicza 9 (2011)

29. R. Conrad, F. Bak, H.J. Seitz, B. Thebrath, H.P. Mayer, H. Schütz, FEMS Microbiol. Lett. 62, 5 (1989)

30. E. Kovács, R. Wirth, G. Maróti, Z. Bagi, K. Nagy, J. Minárovits, G. Rákhely, K. L. Kovács, Bioresour. Technol. 178 (2015)

31. A.H. Igoni, M.J. Ayotamuno, C.L. Eze, S.O.T. Ogaji, S.D. Probert, Appl. Energy 85, 6 (2008)

32. T. Abbasi, D.M. Tauseef, S.A. Abbasi, Biogas Energy (Springer, New York, 2012)

33. L. Deressa, S. Libsu, R.B. Chavan, D. Manaye, A. Dabassa, Environ. Ecol. Res. 3 (2015)

34. M. Bożym, I. Florczak, P. Zdanowska, J. Wojdalski, M. Klimkiewicz, Renew. Energy 77 (2015)

35. Y. Chen, J. J. Cheng, K. S. Creamer, Bioresource Technol. 99, 4044-4064 (2008)

36. G. D. Zupančič, V. Grilc, Managemet of Organic Waste, (InTech, 2012)

37. M. Pawlita-Posmyk, M. Wzorek, Chemik, 10 623625 (2016)

38. A. Król, K. Mizerna, Chemik, 10 (2015)

39. M. Wzorek, Ecol. Chem. Eng. S, 19, 4 (2012), doi: https://doi.org/10.2478/v10216-011-0044-5

40. M. Wzorek, Waste Manage. Res. 32, 5 (2014), doi.org/10.1177/0734242X14529618

41. E. Abdelsalam, M. Samer, Y.A. Attia, M.A. AbdelHadi, H.E. Hassan, Y. Badr, Renewable Energy 87 (2016) 